\title{
Mapping the Literature of Health Education: Textual Analysis of Government Schools Textbooks
}

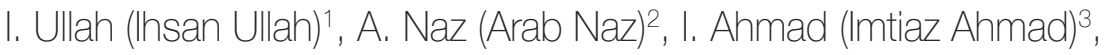 \\ M. Humayun (Muhammad Humayun)4 ${ }^{4}$ F. Ashraf (Faiza Ashraf) ${ }^{5}$
}

${ }^{1}$ Department of Sociology University of Malakand Khyber Pakhtunkhwa, PK.

Original Article

${ }^{2}$ Social Sciences/Chairman Sociology, University of Malakand, Khyber Pakhtunkhwa, PK.

${ }^{3}$ Department of Journalism and Mass Communication, University of Malakand, PK.

${ }^{4}$ University of Malakand, Khyber Pakhtunkhwa, PK.

${ }^{5}$ M.Phil Scholar Sociology University of Lahore, PK.

\section{E-mail address:}

arab_naz@yahoo.com

\section{Reprint address:}

Arab Naz

Social Sciences/Chairman Sociology, University of Malakand

Khyber Pakhtunkhwa

Pakistan

Source: Clinical Social Work and Health Intervention

Volume: 11

Issue: 2

Pages: $34-40$

Cited references: 24

\section{Reviewers:}

Mageswaari Rajoo

Bangkok, Thailand

Selvaraj Subramanian

Kuala Lumpur, Malaysia

\section{Keywords:}

Textbooks. Health Education. Unhygienic Behavior. Infections. Health Literacy.

\section{Publisher:}

International Society of Applied Preventive Medicine i-gap

CSWHI 2020; 11(2): 34 - 40; DOI: 10.22359/cswhi_11_2_07 (C) Clinical Social Work and Health Intervention

\section{Abstract:}

This study aims to see if text books in Khyber Pakhtunkhwa's Swat District contain an adequate amount of literature related to health education. The research methodology used to reach any conclusion(s) regarding health education/promotion contents in government school textbooks was qualitative in nature considering textual analysis of vital subjects taught in $9^{\text {th }}$ and $10^{\text {th }}$ grades in the District. Analysis confirms that school syllabus/books lack health education literature, giving a solemn conclusion that government schools students might remain un- 
able to live a healthy life as adolescents and adults. The study recommends that government schools textbooks should be revised for inclusion of contents related to preventive healthcare measures to enable students to spend a healthy life now as well as during their later life.

\section{Introduction}

Health issues as well as strategies to cope up with them are cornerstones of most policies governments across the globe make irrespective of their economic and political standings. Policymakers are fast realizing that health issues could be greatly resolved if, along with providing topnotch medical facilities at hospitals and other healthcare centers, effective communication strategies are designed for institutions like schools and colleges to make youngsters aware about health problems and their prevention. If governments particularly those of the poor nations start taking appropriate steps for improving health literacy not only would it help decrease the number of patients at hospitals but it would possibly be the first step towards implementation of a comprehensive strategy involving focus on all factors namely social, cultural, biological, psychological, environmental and economic (Jourdan, 2011) which contribute to healthy life of individuals.

Health is quite a subjective matter, different people thinking differently about the meaning of good health varying from individual to individual and community to community (Yazachew, Alem, 2004). WHO believes initiatives like Health Education (HE) consisting of well-planned opportunities in shape of communication designed to improve health literacy like advancement of knowledge and rising life skills will be helpful in developing a society mindful of health issues. (WHO, 1998). The same is called HP or Heath Promotion, meaning educating people about any disease/illness or enabling them to become conscious about their health and thus take solid steps for adopting a healthy lifestyle (WHO, 2005).

Several indispensable authorities have established a strong link between health literacy and school health education precisely stating that the promotion of health literacy is important for students to adopt and maintain healthy behaviors and have enhanced quality of life (Joint Committee on National Health Education Standards, 1995).
Healthy children learn better both physically and psychosocially. Other research asserts that a healthy life as well as successful formal school experience are basically the result of healthy growth in very early childhood particularly during the first 3 years (McCain \& Mustard, 1999).

Community health, no doubt, flourishes at schools, considering the learning institutions are gathering points in any society. Shaping children's minds since early age, schools are important locations for work on health education; with the efforts under way for health education and welfare of students at schools being largely acknowledged. Likewise, major exchange of views on various important forums have long been witnessing discussion on ongoing efforts and the subsequent progress made in connection with health education at school levels. (Pommier, Guevel, Jourdan, 2010).

Since school children comprise a major chunk of society, educational institutions, besides academic responsibilities, have great potential for making community fully aware of health issues as well (Noland et al, 2004). Similarly, other researchers believe that school children's development, growth and body weight are of great significance as they provide us community's general health status (Vashisht, Krishan, Devlal, 2005).

Referring to Hawkins \& Anderson (1996) who put emphasis on health-related dangerous behaviors which effect an individual's emotions, cognitive ability and quality of life, it's important to note that the impact of these risk behaviors on health has resulted in making health education one of the top priorities of top national and international organizations at a global level. (Rutter \& Quine, 2004). And, the same is the case with health promotion at schools in order to avoid health risks in adulthood.

Health education is one of the important tasks for policymakers for primary schools, according to the UNAIDS (1999), with curricular and extracurricular activities at educational centers seen as ideal means to promote health growth. But sadly 
health education, to borrow Bartlett's words, have never remained a priority in school syllabus with stakeholders including teachers and administrators failing to compose an inclusive syllabus containing contents related to health education. (Bartlett, 1981). Health Education has always been considered a 'rainy day' course as the same researcher also asserts that a minor budget is allocated for teaching of such 'rainy day' courses usually taught by poorly-trained and irrelevant professionals.

We need to re-examine our school curriculum, suggests Gulzar (2008). While others lay emphasis on course syllabus since it's considered as an efficient way to facilitate students in their education including health education/promotion (Grunert, 1997; Pastorino, 1999). However, sadly many faculty members hardly give ny thought to developing an inclusive outline (Woolcock, 2003). In fact, it is various life skills programs which can help children and adolescents achieve a healthy life (WHO, 1994). Evidence from China, Guinea, India as well as Mexica show that children with ailments don't attend school since it's illness that stop them from coming to school (Carron \& Chau, 1996). This bring us to the point that interventions regarding promotion of health in schools are becoming emphatically clear. The fact dawning on most stakeholders is that developing countries have long been faced with problems including protein deficiency in children who have sadly been gripped with micronutrient deficiency disorders, helminthic infection and temporary hunger (Levinger, 1992).

Like other disciplines in the field of education, enabling individuals to gain knowhow of HE will not only help the country achieve health targets but also economic context. Ours is sadly a developing nation unfortunately facing poor health statistics. Here the school syllabus is designed in a way that a very meager amount of content related to health education/promotion is included. Likewise, the teaching staff in the provision of health education is untrained. The only noticeable discipline taught to improve healthcare is 'physical education' which hardly covers the basics of preventive healthcare measures and the same is considered as an auxiliary subject. Considering poor status of preventive healthcare prevailing in Pakistani society, these researchers easily observe that a $10^{\text {th }}$ grader irrespective of gender is mostly not able to define normal health which leads individuals to make easily preventable health-related mistakes.

Comparing this scenario to the developed world, it can easily be argued that most people there know some of the very important health concepts while being knowledgeable about the importance of safe drinking water and food; how major infections spread; first aid measures are given/taken; how personal hygiene is taken care of among other preventive healthcare measures.

\section{Argument of the Study}

Preferably, health learning should happen at a young age before negative patterns of behavior and interaction take root. Because of their contact to children and adolescents at a very high level, schools are an appropriate place for the introduction of life skills education (WHO, 1994). According to a research study of US Department of Health and Human Services (2007), health risk behaviors that contribute to leading causes of death are often developed during childhood and prevention is the best cure for chronic disease. School health education provides the basis for inculcating behaviors in our young people to prevent or delay the inception of the leading causes of death. Moreover a WHO (WHO, 2003) research has verified that effective school health programs are powerful and should be launched through a sequenced and well-planned curriculum at both primary and secondary schools before the onset of the risky behaviors.

Individual differences should be focused in preparing curriculum wherein students learning should be target and result-oriented (Glatthorn \& Jailall, 2000). Similarly, the structure of the courses should not be insensitive to gender issues apart from catering for children of diverse abilities and backgrounds. Furthermore, the discipline taught at schools should not ignore other challenging health issues including HIV/AIDS. In a nutshell, it should be based on emphatically-defined learning outcomes which should be properly sequenced and grade-wise (Kraft, 1995).

Also, new evaluation of health education research proves assurance of having an optimistic impact on academic achievement as it has on health outcomes. Well-designed school-based health interventions can facilitate students to prevent disease and injury (Botvin et al, 1995). 
Sadly, the current fields of research show a flawed school syllabus as a result of which students are unaware about basics of their health which in turn leave them exposed to negative mental, physical and social impacts on their wellbeing. The same is the case with Swat's youths who are exposed to various physical and microbial health hazards owing to lack of proper health education at schools in the district.

The focus of this study zeros in on various curricular causes of inadequate health education as a result of which students and the community at large suffer. Although, Swat's literacy rate is high as compared to province of Khyber Pakhtunkhwa's other districts, the school syllabus is quite low on contents related to health issues which are hardly helpful for the greater cause of health education. The major increase in the communicable and non-communicable diseases in this area are easily blamed on the low level of awareness programs about health in schools.

\section{Research Methodology and Results}

During the process of inquiry four of the vital subjects of $9^{\text {th }} \& 10^{\text {th }}$ grades namely Biology, General Science, Health and Physical Education and Islamic Education were selected purposively for content analysis to decipher how much preventive healthcare subject-matter they carry. Considering the main theme of Health Education, a comprehensive page-to-page content analysis of the selected books was conducted the analytical summary of which is presented sequentially below.

Biology for $\mathbf{9}^{\text {th }} \& \mathbf{1 0}^{\text {th }}$ Grades: It is one of the main subjects taught to science students in classes 9 and 10 . The book taught in the discipline has a total of 18 chapters equally divided into 9 and 10 grades. With some information regarding the human body, the contents included in this course are: all about basic biological terms; solution of various biological problems; discussions on composition of cells and tissues; while various other sections cursorily deal with issues like biodiversity, circulation and enzymes.

The same course contains brief deliberations on different systems of gaseous exchange, homeostasis, coordination, support and movement and reproduction. The only chapter apparently related to health education is chapter 8 titled 'Nutrition' wherein the literature deals with various nutrients and a balanced diet apart from other important aspects of human physical needs (see Annex-I). In a nutshell, out of 18 chapters only one chapter is having some information somehow complementing contents related to preventive healthcare measures.

General Science for $9^{\text {th }} \boldsymbol{\&} \mathbf{1 0}^{\text {th }}$ Grades: General Science is one of core subjects in Arts and Humanities taught in $9^{\text {th }} \& 10^{\text {th }}$ grades. Half chapters in a single General Science book are taught in $9^{\text {th }}$ class with the rest in $10^{\text {th }}$ grade. Among all 11 chapters, only two are about human health and diseases with chapter 4 being titled 'Human Health' and chapter 5 named 'Diseases: Causes and Prevention" (see annex-II). However, the fact is that both chapters contain only supportive material in connection with improving students' health while the other nine chapters are about other technical matters.

Health \& Physical Education (HPE) for $9^{\text {th }}$ \& 10 ${ }^{\text {th }}$ grades: There are 19 chapters in this subject with 9 being covered in $9^{\text {th }}$ class while the rest in $10^{\text {th }}$ grade. Textual analysis of health and physical education subject shows that 6 chapters $(1,10,12,13,16 \& 17)$ are about making students aware of health issues (Annex-I) while the rest comprised technical knowhow about athleticism and sports in general. However, the same discipline contains rules and principles related to various physical therapies, exercises and games which don't clearly fall in the gambit of health education. Likewise, other chapters in the book deal with principles of body and joint movements in addition to various other concepts which are hardly related to preventive healthcare measures. Still, no denial of the fact that the 6 chapters having content on health education amply contain literature related to: health education and promotion; with some prominent concepts being the definition of health education; how various diseases are prevented and cured; how school environment could be helpful in a healthy life; discussion on healthy diet and ways to prevent infectious diseases.

Notwithstanding such rich content comprising $30-40 \%$ literature on $\mathrm{HE}$ - the subject of health and physical education has only been catering to $25 \%$ of total students, sadly. (see annex-III).

Islamic Education (Compulsory) for $9^{\text {th }} \boldsymbol{\&}$ $1^{\text {th }}$ Grades: This subject containing a total of 17 Lessons is divided into three parts: Part 1 
having 7 lessons which contain Quranic verses with Urdu translation; Part 2 has only 1 chapter having Hadiths, their Urdu translation and explanation; Part 3 sees interpretation of different religious concepts with the same part containing 9 chapters. Among these 9 chapters only 1 chapter 'Ablution \& Physical Cleanliness' is somehow related to health education (see annex-IV).

\section{Annexure-I Book Contents- Chapter Titles} of Biology for Classes 9 \& 10

\section{Biology for Class 9 \& 10 \\ 1. Introduction to Biology \\ 2. Solving a Biological Problem \\ 3. Biodiversity \\ 4. Cells \& Tissues \\ 5. Cell Cycle \\ 6. Enzymes \\ 7. Bio-energetic \\ 8. Nutrition \\ 9. Transport}

\section{Biology for Class 10}

10. Gaseous Exchange

11. Homeostasis

12. Coordination

13. Support \& Movement

14. Reproduction

15. Inheritance

16. Man \& His Environment

17. Biotechnology

18. Pharmacology

Annex-II Book Contents- Chapter Titles of General Science for Classes 9 \& 10

\section{General Science for Class 9 \& 10}

1. Introduction (The Role of Science)

2. Our Life \& Chemistry

3. Biochemistry \& Biotechnology

4. Man \& His Health

5. Diseases: Causes \& Prevention

6. Environment \& Natural Resources

7. Energy

8. Electricity

9. Electronics

10. Science \& Technology

11. Space Research \& Pakistan Atomic Energy Plan
Annex-III Book Contents- Chapter Titles Health \& Physical Education for Classes $9 \& 10$

\section{Health \& Physical Education for Class 9}

1. Introduction to Physical Education

2. Physical Movements

3. Gymnastics and Physical Activity

4. Posture and Posture Imbalance

5. Massage

6. Physical Fitness- Characteristics of a Good Athlete

7. Tournament System

8. Sports Rules

9. Athletics Rules

Health \& Physical Education for Class 10

10. Importance of Physical Education

11. Recreation and Small Area Games

12. Definition of Health, Community Health and its Importance

13. Health Prevention

14. Training: Physical Exercises for correcting Posture

15. Joints and Muscles

16. Healthy School Environment \& Infectious diseases

17. Our Food

18. Sports Rules

19. Athletics Rules

20. Introduction to Physical Education

21. Physical Movements

22. Gymnastics and Physical Activity

23. Posture and Posture Imbalance

24. Massage

25. Physical Fitness- Characteristics of a Good Athlete

26. Tournament System

27. Sports Rules

28. Athletics Rules

29. Importance of Physical Education

30. Recreation and Small Area Games

31. Definition of Health, Community Health and its Importance

32. Health Prevention

33. Training: Physical Exercises for correcting Posture

34. Joints and Muscles

35. Healthy School Environment and Infectious diseases

36. Our Food

37. Sports Rules

38. Athletics Rules 
Annexure-IV Book Contents- Chapter Titles of Islamic Education (Compulsory) for Classes 9 \& 10

\section{Book Name and its Contents Islamic Education (Compulsory) for Classes 9 \& 10}

Part-I

Initial 7 chapters contain Quranic Verses \& Translation

\section{Part-II}

Chapter 8- Ahadith \& Translation

\section{Part-III}

1. Introduction to Quran

2. Following Allah \& His Prophet (PBUH)

3. Knowledge \& its Importance

4. Zakat

5. Physical Cleanliness

6. Patience \& Our individual \& Collective Life

7. Importance of Daily Life

8. Migration \& Jihad

9. Human Rights

\section{Conclusion}

Textual analysis of textbooks shows that the contents regarding health education are insufficient and provide students with inadequate knowledge about preventive healthcare measures. The main discipline about health education namely HPE contains sizeable percentage points -between $30 \%$ and $40 \%$ - of material about health education and health promotion but sadly the discipline is taught to a low number of Arts students, bringing us to the point that only the discipline of HPE is having a sufficient amount of literature - that is more than one third of the total health and physical education subject content - but it is taught to only $25 \%$ students while the rest of the books absolutely lack any HE material.

Speaking conclusively, it is evident that government school text books lack any contents regarding health education and promotion resulting in failure of students to lead a healthy life by protecting themselves from various diseases. The same make students adopt unhygienic behavior which influences their health in adolescence as well as adulthood. In a nutshell, it can be hypothesized that:

"Limited health education contents in current school syllabus leads to various ailments and adoption of unhealthy behavior among students in their early and later life".

\section{Suggestions}

1 Students in government schools must be offered health education through a course outline which is comprehensive and helpful in attaining practical skills to make individual's health improve. Also, the same discipline must provide knowledge regarding major infective diseases to students of all shades.

2 Basic contents of health education like handwashing technique, first aid measures, transmission and prevention of major infectious diseases among other preventive healthcare measures must be included in an HPE syllabus. Furthermore, HPE syllabus should be offered to both Arts and Science students.

3 The Public Health Department must develop a uniform health education curriculum for schools as well as for training HPE teachers to help students develop a health protective behavior.

4 Also, an HPE book sufficient in HE contents like first aid measures etc. must be provided in schools, homes and grounds apart making the discipline of HPE compulsory for science students.

\section{References:}

1. BARTLETT EE (1981) The Contribution of School Health Education to Community Health Promotion: What Can We Reasonably Expect? Am J Public Health, 71, 1384-1391.

2. BOTVIN GJ, BAKER E, DUSENBURY L, BOTVIN EM, DIAZ T (1995) Long-term Follow-up Results of a Randomized Drug Abuse Prevention Trial in a White Middleclass Population. JAMA; 273(14):1106-12.

3. CARRON G, CHAU TN (1996) The quality of primary schools in different development contexts. Paris: UNESCO.

4. ERRECART, MT, WALBERG, HJ, ROSS, JG, GOLD, RS, FIELDER, JF, KOLBE, LJ (1991) Effectiveness of Teenage Health Teaching Modules. Journal of School Health. 61(1).

5. GLATTHORN A, JAILALL J (2000) Curriculum for the new millennium. In Brandt, R. (ed.), Education in a new era: ASCD Yearbook 2000. Alexandria, Virginia.

6. GRUNERT J (1997) The Course Syllabus: A Learning-centered Approach. Bolton, MA: Anker Publishing Company. 
7. GULZAR S (2008, June 16) Promoting school health in Pakistan. The Daily Dawn, p.7.

8. HAWKINS N, ANDERSON R (1996) The Effect of Exercise on Cognitive Functioning among the Elderly. TCA Journal, 24 (2), 1826.

9. JOURDAN D (2011) Health education in schools. The challenge of teacher training Saint-Denis : Inpes, College. Sante en action: $144 \mathrm{p}$.

10. JOINT COMMITTEE ON NATIONAL HEALTH EDUCATION STANDARDS (1995) Achieving health literacy: An investment in the future. Atlanta, GA: American Cancer Society.

11. KRAFT R (1995) An international curricular perspective on decentralization: An introduction to its problems, prospects and evaluation. Paper presented at Ethiopian Curriculum Policy Workshop, Addis Ababa, October 2325, 1999. Washington, D.C.

12. LEVINGER B (1992) Promoting child quality: Issues, trends, and strategies. Paper prepared for the Social Sector Policy Analysis Project, U.S. Agency for International Development, Bureau of Research and Development, Office of Education.

13. MCCAIN M, MUSTARD JF (1999) Reversing the real brain drain: Early years study. Toronto, Canada: Publications Ontario.

14. NOLAND VJ, TROXLER C, TORRENS SALEMI, AM (2004) School health is public health. Florida Public Health Review, 1. Available: http://publichealth.usf.edu/fphr (Access 13 March, 2014).

15. PASTORINO EE (1999) Students with Academic Difficulty: Prevention and Assistance. APS Observer, 12(9), 10-11.
16. POMMIER J, GUEVEL MR, JOURDAN D (2010) Evaluation of Health Promotion in Schools: A Realistic Evaluation Approach using Mixed Methods. BMC Public Health, 10 (43), 1- 12. doi:10.1186/1471-2458-10-43.

17. RUTTER D, QUINE L (2004) Changing Health Behavior. Open University Press. UNAIDS (1999) Sex and Youth: Contextual Factors affecting Risk for HIVIAIDS. Geneva: Best Practice Collection.

18. VASHISHT RN, KRISHAN K, DEVLAL S (2005) Physical Growth and Nutritional Status of Garhwali Girls. Indian J Pediatric, 72(7), 573-8.

19. W.H.O. (2003) Information series on school health: Skills for health; Retrieved June 3, 2014 from http://www.who.int/school_ youth_health/media/en/sch_skills4health_03. pdf.

20. W.H.O. (1994) Program on Mental Health. Geneva: Switzerland.

21. W.H.O. (1998) List of Basic Terms: Health Promotion Glossary. New York. WHO Publication.

22. W.H.O. (2005)The Bangkok Charter for Health Promotion in a Globalized World. Participants at the 6th Global Conference on Health Promotion. Geneva, Switzerland.

23. WOOLCOCK M J V (2003). Constructing a Syllabus. Available: (Access 28 Dec. 2013) .http://www.lac2000.revolta.com/library/syllabus.htm .

24. YAZACHEW M, ALEM Y (2004) Introduction to Health Education. Jimma University. U.S. Department of Health and Human Services (2007) Healthy Youth: An Investment in Our Nation's Future. Atlanta, GA: U.S. 